\title{
Characterization of mango (Mangifera indica L.) genotypes based on physio-chemical quality attributes
}

\author{
Lokesh Bora*, A. K. Singh and C. P. Singh \\ Pantnagar, 263145 (Uttarakhand), INDIA \\ *Corresponding author. E-mail: lokeshbora36099@gmail.com \\ Received: December 19, 2016; Revised received: May 22, 2017; Accepted: October 7, 2017
}

${ }^{1}$ Department of Horticulture, College of Agriculture, G.B. Pant University of Agriculture and Technology,

\begin{abstract}
Evaluation of fruit crops has been successfully utilized for studying the performance of varieties under different agro climatic regions time to time. In the present study cultivars were characterized on the basis of their physico-biochemical attributes. "Mallika" and "Neelgoa" were found superior in terms of fruit weight (321.87 g), size $(12.55 \mathrm{~cm}, 8.13 \mathrm{~cm})$, pulp weight $(257.91 \mathrm{~g})$ and pulp stone ratio $(7.71)$ respectively. "Mallika" excelled in terms of sugar (20.82), while "Amrapali" in carotenoids (8.38 mg/100 g). Among them, Mallika $\left(22.41^{\circ} \mathrm{B}\right)$ possessed the highest amount of total soluble solids while lowest amount in Langra $\left(16.90{ }^{\circ} \mathrm{B}\right)$ whereas maximum titrable. The study shows the potential of Amrapali in terms of its quality, being late can meet the demand for later period when no other cultivar is available.
\end{abstract}

Keywords: Biochemical, Characterization, Evaluation, Mango, Physical

\section{INTRODUCTION}

The evaluation of genotypes is an important process in order to screen the potential cultivars from the collection for any specific region. Although a cultivar may express a unique behaviour under certain area, but it may fail or sustain that peculiar character when grown under different location. The genetic diversity within mango offers various opportunities to utilize these genomic resources and technologies to manipulate desirable traits. India has the richest germplasm collection and centre for cultivating mangoes. Assessment of genetic variation within natural populations and among breeding lines is crucial for effective conservation and exploitation of genetic resources for crop improvement programs. In India, mango occupies a production share of $20.7 \%$ with an area of 2.21 million tonnes, annual production of 18.50 million tonnes having productivity of 8.3 metric tonnes per hectare (Anonymous, 2015). Proper identification of genetic resources is the basic need for carrying out successful improvement work. Characterization is an important aspect for documentation of the performance of the studied cultivars, which would help to introduce, select and improve the existing mango varieties. For easing this work of characterization, IPGRI (2006) has developed the descriptors which do not emphasize much on biochemical parameters. Continuous studies on performance and evaluation help us to select an ideal cultivar for the specific region, which can help us to promote its cultivation and also help to fetch good price in the market on the basis of its quality characters.

Various studies has been carried out on the morphological diversity and horticultural attributes of Indian mangoes (Kumar et al., 1999, Singh and Bana, 1976). Development of mango hybrids that are efficient in nutrient utilization, provide better return and also able to endure adverse environmental conditions, forms the major aims of modern fruit breeding (Khan, 2004). An ideal mango cultivar should have characters like precocious, dwarf, regular and prolific in bearing, early flowering and fruit setting, attractive fruit color and size, resistant to major diseases and other biotic-abiotic stresses (Litz, 2009). The application of morphological characterization is the simplest of the formal, standardized and repeatable method of evaluating crop genetic diversity. Some of the most important advantage of using morphological characterization are that published descriptor lists are readily obtainable for most major crop species, it can be carried out in situ, is relatively low- cost and easy to perform. Morphological characterization is the first step that should be done before more profound biochemical or molecular studies are carried out (Hoogendijk and Williams, 2001). However, interpretation of genetic diversity on the basis of morphological characters has several limitations. Morphological characters have complex inheritance pattern and are vulnerable to environmental conditions. Evaluation forms an important aspect for studying the constant performance of genotypes in a particular environment. Hence, an attempt was made to evaluate the physiochemical quality of the potential geno- 
types of mango under tarai region of Uttarakhand.

\section{MATERIALS AND METHODS}

The experiment was carried out on fourteen (14) hybrids and five (5) superior selections of mango at Horticulture Research Centre, Patharchatta in year 2014. The selected genotypes were of 6 years old during evaluation. All the plants selected for the experiment were almost uniform in growth and vigor. The uniform cultural practices (fertilizers) were adopted for all the selected cultivars of mango under the experimentation. The experiment was laid out in Randomized Block Design (RBD) with three replications. The 19 genotypes containing 14 hybrids and 5 selections of mango were considered as treatments.

Physical parameters: The physical parameters such as fruit weight, size, pulp weight and thickness, stone size and thickness were measured using twelve (12) fruits of mango from different replication under each treatment, randomly selected and weighed using top pan balance. The length and diameter were measured using digital Verniercalliper and expressed in grams $(\mathrm{g})$, millimeters $(\mathrm{mm})$ and centimeters $(\mathrm{cm})$, respectively.

Biochemical characteristics: The total soluble solids of fruits were measured by using digital hand refractrometer (Atazo, Japan) at room temperature and results were expressed in terms of degree Brix $\left({ }^{\circ} \mathrm{B}\right)$. The titrable acidity was determined by titrating $10 \mathrm{ml}$ aliquot against $0.1 \mathrm{~N}$ sodium hydroxide solution using phenolphthalein as indicator. The result was expressed as per cent citric acid. The reducing sugar, nonreducing and total sugar were estimated and expressed in percentage. The extract was taken and titrated against $10 \mathrm{ml}$ of mixed Fehling solution A and B using methylene blue as indicator. The results were expressed as percent of reducing sugar. The sugar extract was hydrolyzed with concentrated hydrochloric acid and titrated against $10 \mathrm{ml}$ of mixed Fehling's solution (5 ml Fehling A $+5 \mathrm{ml}$ Fehling solution B) using methylene blue as indicator. Results were expressed as per cent total sugar. The amount of non-reducing sugar was calculated by subtracting reducing sugars from total sugar and multiplying the difference by factor 0.95 as suggested by AOAC (1980). The Ascorbic acid content was estimated by using 2, 6-Dichlorophenolindophenol visual titration method (Ranganna, 1986). All the chemicals used were of AR grade. Ascorbic acid in terms of mg per $100 \mathrm{~g}$ pulp weight was calculated by using the following formula:

$$
\text { Ascorbic acid }(\mathrm{mg} / 100 \mathrm{~g})=\frac{\text { dye factor } x \text { titre reading } x \text { dilution } x 100}{\text { weight } x \text { Volume of a sample }}
$$

Total carotenoids content: One gram of sample was weighed and grinded with acetone using acid and alkali washed sand in a pestle and mortar. The extract was decanted into a conical flask. The extraction is contin- ued till the residue become colorless. The acetone extract was transferred to a separating funnel containing $10-15 \mathrm{ml}$ of petroleum ether and mixed gently. After addition of $25 \mathrm{ml}$ of $5 \%$ Sodium sulphate $\left(\mathrm{Na}_{2} \mathrm{SO}_{4}\right)$, the solution was shaken and kept for 5-10 min. The separated yellow color pigment was transferred into the petroleum ether later. The layer was collected in a volumetric flask and acetone layer containing $\mathrm{Na}_{2} \mathrm{SO}_{4}$ was separated until the colourgets transferred into the petroleum ether. The colourintensity was measured at $452 \mathrm{~nm}$ by using spectrophotometer and the total carotenoids content was calculated by the following formula (AOAC , 1984).

Total Carotenoids $(\mathrm{mg} / 100 \mathrm{~g})=\frac{\text { a.s57 } \times 0 . \mathrm{D} \times \text { Wolume made up }(\mathrm{ml}) \times 100}{\text { weight of sample }(\mathrm{g}) \times 100}$

Statistical analysis: The different observations were subjected to statistical analysis by using randomized block design (RBD). The mean difference was tested by ' $F$ ' test at 5 percent level of significance (LOS). Critical difference (CD) at 5 per cent level of probability was used for comparison among treatments. Data were subjected to analysis of variance (ANOVA) by using STPR3 software (GBPUAT, Pantnagar, India). Analysis of physico-biochemical data was subjected DARwin5 software, version 5.0.158 developed by CIRAD, Research unit "Genetic improvement of Vegetatively Propagated Crops" for construction of phylogenetic tree (Perrier and Jacquemound, 2006).

\section{RESULTS AND DISCUSSION}

Fruit physical parameters: Data related to fruit weight presented in Table 1, revealed that a wide range of fruit weight (94.17-340.17 g) was observed in different cultivars of mango. The higher fruit weight was found in Mallika (340.17 g) followed by Neelgoa (335.50 g), Pusa Surya (329.17 g),Langra (308.33 g) and they were found statistically at par with each other. The lower fruit weight was observed in Dashehari Clone (94.17 g), which was statistically at par with Amrapali (101.74g). The higher or lower fruit weight might be due to the varietal or genetic characters. The similar trend in the variation of fruit weightfrom 365.33-219.00 has also been reported by Majumder et al., 2011,while evaluating different mango cultivars. The mean value for the fruit length ranged from $7.21 \mathrm{~cm}$ to $12.55 \mathrm{~cm}$. The higher fruit length was recorded in cv. Mallika $(12.55 \mathrm{~cm})$ followed Ambika $(11.96 \mathrm{~cm})$ and Pusa Arunima $(11.88 \mathrm{~cm})$.

The mean value of fruit width showed a range of 5.07 $\mathrm{cm}$ to $8.85 \mathrm{~cm}$. The higher fruit width was reported in Vanraj $(8.85 \mathrm{~cm})$, which was statistically at par with Langra $(8.66 \mathrm{~cm})$. The variation in length $(11.50-6.86)$ and width (10.96-5.37) of fruit in mango was also observed by Kher and Sharma (2002) and Abiramiet al. (2008).The variations in the fruit size depend upon the genetic makeup of an individual variety and are highly influenced by environmental factors. 


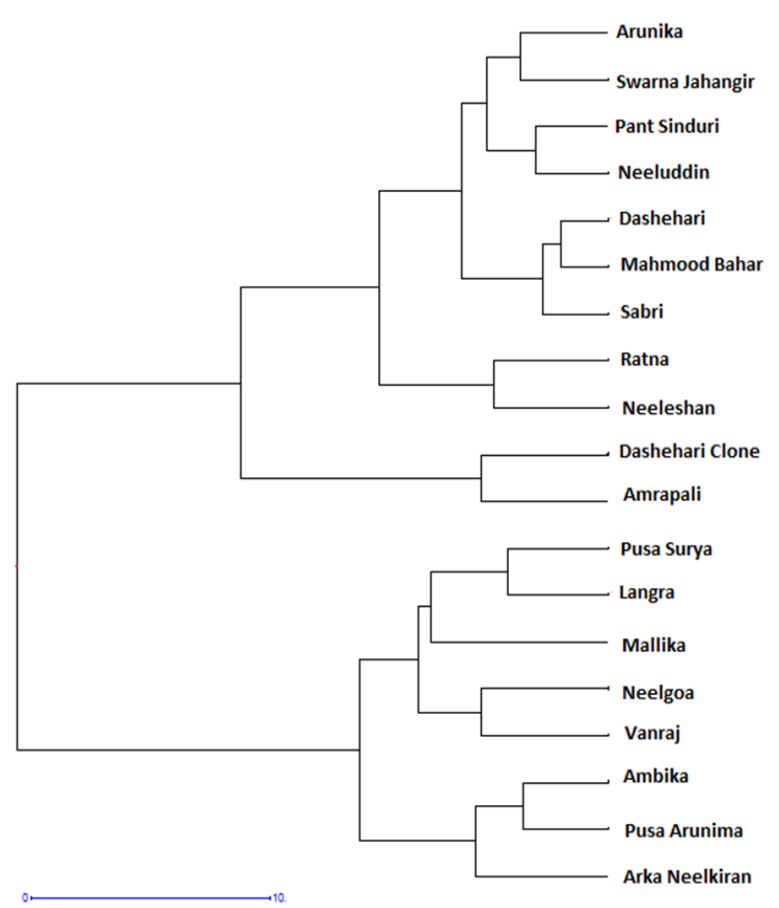

Fig. 1. Clustering of 19 mango (Mangifera indica L.) cultivars based on quantitative data of morpho- physical and biochemical characters.

The mean value of the peel weight ranged from $13.5 \mathrm{~g}$ to $40.50 \mathrm{~g}$. The minimum peel weight was noted in Neeluddin (13.5 g), which was statistically at par with Pant Sinduri (16.28 g). The maximum peel weight was exhibited by Ratna (40.50 g), which was statistically at par with Neelgoa (39.66 g). The present finding related to peel weight are also in accordance with the results of Anila and Radha (2005) who observed the highest peel weight (51.74 g) in Ratna. Mitra and Mitra (2001) evaluated 19 cultivars and reported difference in peel weight in various cultivars. The significant differenceat $0.05 \%$ was also found with respect to the peel thickness. The mean value of peel thickness ranged from $0.67 \mathrm{~mm}$ to $1.53 \mathrm{~mm}$. Similar trends of results were also obtained by Mannan et al. (2003), who reported the range of peel thickness varied from $1.48 \mathrm{~mm}$ to $2.72 \mathrm{~mm}$ in different mango varietiesviz., Amrapali, Fazli, Neelambari, Indian Tota and MadraziTota. Peel thickness provides a protection against fruit fly and help to reduce post harvest losses, however this fact could increase the difficulty of removing peel before processing. It is evident from the data that the mango cultivars significantly differed with respect to their pulp weight. Mallika ranked first in pulp weight $(257.91 \mathrm{~g})$ followed by Langra $(226.09 \mathrm{~g})$ and Neelgoa (224.68 g). The lower pulp weight was recorded in cv. Dashehari Clone (32.59 g) which was statistically at par with Amrapali $(55.25 \mathrm{~g})$. The lower pulp weight in cultivar Dashehari Clone was due to its smaller fruit size.

The stone weight varied significantly among the different cultivars of mango under study. The lower weight of stone was observed in Dashehari Clone (12.49 g) followed by Amrapali (22.99 g) and Neeluddin (23.60 g). The higher stone weight was recorded in cv. Langra $(35.06 \mathrm{~g})$. Significant variation $(0.05 \%)$ in stone length and width of different mango cultivars was also reported by Kundu and Ghosh (1992) and Abirami et al. (2004).The present findings related to stone weight are also in accordance with the results of Jilaniet al. (2010) and Anila and Radha (2005), who observed that stone weight ranged from $22.99 \mathrm{~g}$ to $47.07 \mathrm{~g}$ in four varieties and two hybrids viz., Alphonso, Prior, Muvandan, Neelum and hybrids Ratna (Neelum x Alphonso) and H-151 (Kalapady x Neelum). The data on ratio of pulp and stone clearly revealed that the variety Mallika (7.71) had higher ratio followed by Vanraj (7.52). The lower values were obtained for Amrapali (2.40) followed by Dashehari Clone (2.61) and Mehmood Bahar (2.71). Stone size is an important character of mango as it determines the edible portion in the fruit. The lower stone length was noted in cv. Arunika $(5.74 \mathrm{~cm})$ which was statistically at par with Dashehari Clone $(5.91 \mathrm{~cm})$, Sabri $(6.17 \mathrm{~cm})$, Swarna Jahangir $(6.28 \mathrm{~cm})$ and Langra $(6.58 \mathrm{~cm})$.

The mean value for the stone width showed a range of 2.33 to $4.11 \mathrm{~cm}$. Minimum stone width was noticed in cv. Dashehari $(2.33 \mathrm{~cm})$ which was statistically at par with Dashehari Clone $(2.70 \mathrm{~cm})$. The maximum stone width was observed in Neelgoa $(4.11 \mathrm{~cm})$, which was statistically atpar with Pusa Surya $(4.03 \mathrm{~cm})$, Mallika $(4.01 \mathrm{~cm})$, Mahmood Bahar $(3.85 \mathrm{~cm})$, Pusa Arunima $(3.77 \mathrm{~cm})$, Ratna $(3.73 \mathrm{~cm})$, and Ambika $(3.62 \mathrm{~cm})$.

The higher stone thickness was observed in Sabri (2.32 $\mathrm{cm})$ followed by Pant Sinduri $(2.18 \mathrm{~cm})$. The lower stone thickness was observed in Neeleshan $(1.51 \mathrm{~cm})$, which was statistically at par with Neelgoa $(1.64 \mathrm{~cm})$, Dashehari $(1.66 \mathrm{~cm})$ and Dashehari Clone $(1.72 \mathrm{~cm})$. Significant variation in stone length and width in different mango varieties was also recorded by Abirami et al. (2004) in (Bappakal, Chandrakaran, EC-95862, Kensington, Kitchner, Kurukkan, Muvandan, Mylepelian, Nekkare, Olour, Peach, Prior and Starch. This variation in stone characteristics might be due to different in environmental interaction and genetic composition.

Chemical characteristics: On the basis of the analysis it was observed that mango cultivar, Mallika $\left(22.41^{\circ} \mathrm{B}\right)$ possessed higher amount of TSS followed by Neelgoa $\left(21.71^{\circ} \mathrm{B}\right)$, ArkaNeelkiran $\left(21.62^{\circ} \mathrm{B}\right)$, Dashehari (21.44 $\left.{ }^{\circ} \mathrm{B}\right)$, Sabri (21.33 $\left.{ }^{\circ} \mathrm{B}\right)$, Mahmood Bahar (21.29 $\left.{ }^{\circ} \mathrm{B}\right)$, Arunika $\left(21.33{ }^{\circ} \mathrm{B}\right)$, Neeluddin $\left(20.45^{\circ} \mathrm{B}\right)$, Pusa Surya $\left(20.06{ }^{\circ} \mathrm{B}\right)$, Amrapali $\left(20.12{ }^{\circ} \mathrm{B}\right)$ and PusaArunima $\left(19.99{ }^{\circ} \mathrm{B}\right)$. A lower amount of T.S.S was observed in Langra $\left(16.90{ }^{\circ} \mathrm{B}\right)$, followed by Dashehari Clone $\left(18.68{ }^{\circ} \mathrm{B}\right)$, Ambika (19.20 $\left.{ }^{\circ} \mathrm{B}\right)$ and Pant Sinduri (19.36 $\left.{ }^{\circ} \mathrm{B}\right)$. Therefore in the present investigation the variation 
Lokesh Bora et al. / J. Appl. \& Nat. Sci. 9 (4): 2199 - 2204 (2017)

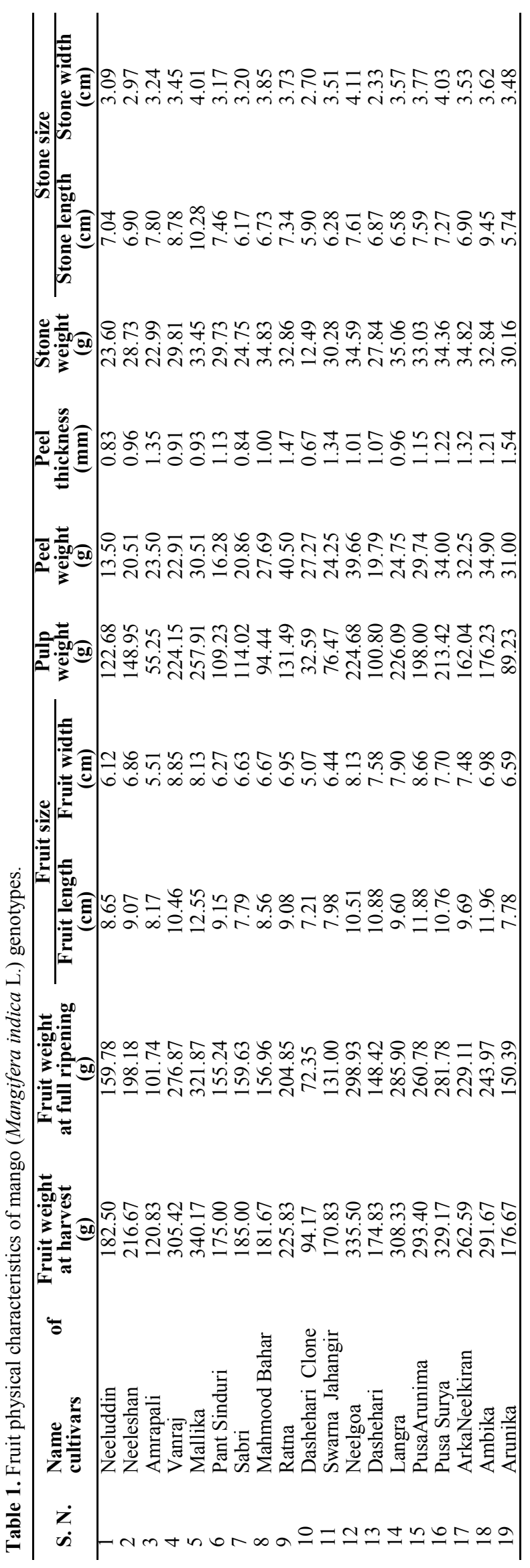

in TSS ranged from $16.90{ }^{\circ} \mathrm{B}$ to $22.41^{\circ} \mathrm{B}$, however these findings partially agreed with the results of Bhuyan and Guha (1995), who also reported TSS from 16.22 to $24.14{ }^{\circ} \mathrm{B}$ in 14 mango germplasm under the climatic conditions of Rajshahi. Similar variation was also reported by Teaotia et al. (1972) and Samad et al. (1975) in mango fruits. Variation in TSS $\left(16.11{ }^{\circ} \mathrm{B}\right.$ to 23.00 $\left.{ }^{\circ} \mathrm{B}\right)$ is also reported by Singh (2002).

The maximum titrable acidity was observed in Langra $(0.29 \%)$ followed by Swarna Jahangir $(0.25 \%)$, whereas its minimum content was found in Ratna $(0.14 \%)$ \&Sabri $(0.14 \%)($ Table 2$)$. The ratio of TSS: acidity was found maximum in Sabri (152.35) followed by Neelgoa (144.73) and Dashehari (142.93), whereas Langra registered minimum ratio of TSS and acidity (58.27) followed by Neelgoa (47.02). The values of titrable acidity are in accordance with the results of Kumar (1998), who reported the range of 0.17 to 0.33 $\%$ in different mango cultivars. Its wide range of values from 0.11 to $0.43 \%$ was also supported by Bakshi and Bajwa (1959). The variation in the acidity in the different varieties of mango could be due to their varietal characters. Moreover, the TSS acidity ratios as reported in present study were similar to those of Palaniswamy et al. (1975). The similar findings have also been reported by Mitra et al. (2001), Dhillon et al. (2004), Sharma and Josan (1995) and Kher and Sharma (2002) while working on fruit quality characters of different mango varieties under different climatic conditions. Kher and Sharma (2002) and Hoda et al. (2003) also reported the similar trend of variation i.e., 39.36 to 152.39 in sugar percentage in different mango cultivars.

The higher total sugar content was recorded in Mallika (20.82\%) followed by Arunika (18.11\%) and Neelgoa $(17.61 \%)$, whereas lower in Neeleshan (15.23 \%) followed by Ratna $(16.21 \%)$. The reducing sugar was found maximum in Arka Neelkiran (7.13\%) followed by Neeleshan $(6.89 \%)$, whereas minimum in Pant Sinduri (4.66 \%) followed by Sabri (4.86\%) and Mallika (4.98\%). The higher non reducing sugar was recorded in the cultivar Mallika (15.04\%) followed by Sabri $(12.15 \%)$ and Pant Sinduri (11.89\%), while lower in cv. Neeleshan $(7.92 \%)$ followed by Arka Neelkiran $(9.26 \%)$. Among all the cultivars under studied Langra possessed the higher amount of ascorbic acid content $(55.62 \mathrm{mg} / 100 \mathrm{~g})$ followed by Pusa Surya (46.25 $\mathrm{mg} / 100 \mathrm{~g}$ ) and PusaArunima (45.63 mg/100g), however, lower in Vanraj $(24.38 \mathrm{mg} / 100 \mathrm{~g})$ and Sabri $(24.60$ $\mathrm{mg} / 100 \mathrm{~g})$. A wide variation in ascorbic acid content $(2.90$ $\mathrm{mg} / 100 \mathrm{~g}-136.50 \mathrm{mg} / 100 \mathrm{~g}$ ) has been reported by Doreyappa and Ramanujaneya (1994). Mitraet al. (2001) observed the ascorbic acid content in the range of 21.66 $\mathrm{mg} / 100 \mathrm{~g}-125.40 \mathrm{mg} / 100 \mathrm{~g}$. Such variation in ascorbic acid content could be attributed to the nature and extent of genetic variability present in the experimental material.

The maximum carotenoids content was observed in Amrapali $(8.38 \mathrm{mg} / 100 \mathrm{~g})$ followed by Mallika (7.42 
Table 2. Content of TSS, titrable acidity, sugars and total carotenoids of mango (Mangifera indica L.) genotypes.

\begin{tabular}{|c|c|c|c|c|c|c|c|c|}
\hline \multirow[b]{2}{*}{ S. N. } & \multirow{2}{*}{$\begin{array}{l}\text { Name } \\
\text { cultivars }\end{array}$} & \multirow{2}{*}{$\begin{array}{l}\text { TSS } \\
\left({ }^{\circ} \mathrm{B}\right)\end{array}$} & \multirow{2}{*}{$\begin{array}{c}\text { Acidity } \\
(\%)\end{array}$} & \multicolumn{3}{|c|}{ Sugars } & \multirow{2}{*}{$\begin{array}{c}\text { Ascorbic acid } \\
\text { (mg/100 g) }\end{array}$} & \multirow{2}{*}{$\begin{array}{c}\text { Total ca- } \\
\text { rotenoids } \\
(\mathrm{mg} / 100 \mathrm{~g})\end{array}$} \\
\hline & & & & $\begin{array}{c}\text { Total sugar } \\
(\%)\end{array}$ & $\begin{array}{l}\text { Reducing } \\
\text { sugar }(\%)\end{array}$ & $\begin{array}{c}\begin{array}{c}\text { Non-reducing } \\
(\%)\end{array} \\
\end{array}$ & & \\
\hline 1 & Neeluddin & 20.45 & 0.22 & 17.39 & 5.42 & 11.37 & 37.57 & 2.53 \\
\hline 2 & Neeleshan & 19.53 & 0.18 & 15.23 & 6.89 & 7.92 & 36.88 & 2.73 \\
\hline 3 & Amrapali & 20.12 & 0.25 & 17.30 & 5.89 & 10.84 & 31.89 & 8.38 \\
\hline 4 & Vanraj & 19.46 & 0.16 & 17.51 & 5.84 & 11.09 & 24.38 & 2.01 \\
\hline 5 & Mallika & 22.41 & 0.24 & 20.82 & 4.98 & 15.04 & 37.08 & 7.42 \\
\hline 6 & Pant Sinduri & 19.36 & 0.17 & 17.17 & 4.66 & 11.89 & 33.75 & 3.03 \\
\hline 7 & Sabri & 21.33 & 0.14 & 17.64 & 4.86 & 12.15 & 24.61 & 1.75 \\
\hline 8 & Mahmood Bahar & 21.29 & 0.15 & 17.38 & 6.01 & 10.81 & 25.63 & 1.53 \\
\hline 9 & Ratna & 19.57 & 0.14 & 16.21 & 5.57 & 10.11 & 43.13 & 2.64 \\
\hline 10 & Dashehari Clone & 18.68 & 0.23 & 16.60 & 6.44 & 9.65 & 30.63 & 1.58 \\
\hline 11 & Swarna Jahangir & 20.01 & 0.25 & 16.98 & 5.50 & 10.91 & 33.03 & 1.60 \\
\hline 12 & Neelgoa & 21.71 & 0.15 & 17.61 & 5.50 & 11.50 & 32.50 & 2.74 \\
\hline 13 & Dashehari & 21.44 & 0.15 & 17.33 & 5.45 & 11.29 & 32.50 & 2.95 \\
\hline 14 & Langra & 16.90 & 0.29 & 16.86 & 5.72 & 10.58 & 55.62 & 2.60 \\
\hline 15 & PusaArunima & 19.99 & 0.16 & 17.03 & 6.06 & 10.43 & 45.63 & 4.24 \\
\hline 1 & Pusa Surya & 20.06 & 0.24 & 16.54 & 6.23 & 9.79 & 46.25 & 2.47 \\
\hline 17 & ArkaNeelkiran & 21.62 & 0.19 & 16.88 & 7.13 & 9.26 & 27.72 & 2.55 \\
\hline 18 & Ambika & 19.20 & 0.15 & 16.37 & 5.26 & 10.56 & 30.00 & 4.20 \\
\hline 19 & Arunika & 21.33 & 0.21 & 18.11 & 5.72 & 11.78 & 29.56 & 3.50 \\
\hline \multicolumn{2}{|l|}{ S.Em \pm} & 00.86 & 0.01 & 0.66 & 0.42 & 0.66 & 2.17 & 0.28 \\
\hline \multicolumn{2}{|c|}{$\mathrm{CD}$ at $5 \%$} & 2.47 & 0.04 & 1.88 & 1.21 & 1.90 & 6.24 & 0.81 \\
\hline
\end{tabular}

$\mathrm{mg} / 100 \mathrm{~g})$, whereas the minimum in Mahmood Bahar $(1.53 \mathrm{mg} / 100 \mathrm{~g})$. These findings are in agreement with observations made by Singh (2002). Variation in total carotenoids contents in the range of $2.33 \mathrm{mg} / 100 \mathrm{~g}-44.95$ $\mathrm{mg} / 100 \mathrm{~g}$ was also recorded by Hoda et al. (2003). Total carotenoids provide an expression of natural appearance to the fruit product and their higher content in fruits offer distinct advantages, particularly in international trade where addition of artificial color is discouraged. Still some of the unexplored region of Uttarakhand possesses the diverse germplasm of mango with different behaviour of fruiting habits, which need to be timely surveyed and analyzed for their quality parameters.

Construction of dendrogram based on Morpho-physico and biochemical characters: By drawing similarity tree considering qualitative biochemical data using DARwin5 software figure 1 was obtained. There were two major clusters. The bigger cluster (supposedly 'Cluster -A') comprises of 13 genotypes. In Cluster-A two main sub-clusters (a1 and a2) are formed. In the first sub-cluster (a1) 11 genotypes Arunika, Swarna Jahangir, Pant Sinduri, Neeluddin, Dashehari, Mahmood Bahar, Sabri, Ratna, Neeleshan, Dashehari Clone and Amrapali. The other sub cluster viz., (a2) containing two genotypes namely, Pusa Surya, Langra, Mallika, Neelgoa, Vanraj, Ambika, Pusa Arunima and Arka Neelkiran. The smaller cluster (supposedly Cluster-B) consisted of 6 genotypes which were divided into two sub-clusters $b_{1}$ and $b_{2}$. The first cluster $\left(b_{1}\right)$ comprises Arunika, Swarna Jahangir, Pant Sinduri, Neeluddin, Dashehari, Mahmood Bahar, Sabri, while Ratna, Neeleshan, Dashehari Clone and Amrapali categorized under $\left(b_{2}\right)$. The clustering of genotypes is based on the basis of the trait in which the share the similarity. The genotypes were grouped based on the degree to which they were similar in the biochemical characters. The categorization of genotypes can help to short out the similarity in their traits observed based on quality parameters. However these quality traits may vary from time to time and region to region, as the performance and quality of fruit is favoured depending upon the favourable environmental conditions, and expression of the genes responsible for the desired traits. Therefore constantly the evaluation studies need to be taken to short out the best cultivar for a region.

\section{Conclusion}

On the basis of findings of the present study, it can be concluded that the significant variation exist within the genotypes based on physico-chemical characters. "Sabri" and "Amrapali" have shown dwarfing behaviour $(1.45 \mathrm{~m})$, while "Swarna Jahangir" was found to be vigorous in growth $(3.42 \mathrm{~m})$. "Mallika" and "Neelgoa" were found superior in terms of fruit weight (340.17 and $335.50 \mathrm{~g}$ ), size, pulp weight (224.68 g) and pulp stone ratio (6.50). "Mallika" excelled interms of sugar (20.82\%), while "Amrapali" in carotenoids $(8.38 \mathrm{mg} / 100 \mathrm{~g})$. The higher altitude of Uttarakhand still possesses the diverse germplasm which can be used for hybridization purpose and efficient exploration should be undertaken to exploit the potential. Therefore characterization forms an important prerequisite for starting a breeding programme.

\section{ACKNOWLEDGEMENTS}

The author is highly thankful to the Department of Horticulture for granting graduate assistantship for conducting present research. 


\section{REFERENCES}

Abirami, K., Nacheggowda, V. and Reddy $\mathrm{Y}$ T N. (2004).Physico- chemical attributes of certain polyembryonic varieties of mango. South Indian Hort.,52(1/6): 291-296

Anila, R and T. Radha. (2005).Physico-chemical analysis of mango varieties under kerala conditions.J. of Trop. Agri.,41: 20-22

Anonymous.(2015). Horticultural Statistics at a Glance National Horticulture Board, Gurgaon, Haryana

AOAC (1980). Official Methods of Analysis.13th edition.Association of Official Analytical Chemists, Washington, D.C.

Association of Official Analytical Chemists - AOAC.(1984). Official methods of analysis. 13th ed. Washington. 195417

Bakshi, J. C. and Bajwa, B. S. (1959). Studies on varietal differences in fruit quality of mango varieties grown in Punjab.Indian J. of Hort., 16: 216-220

Bhuyan, M. A. J. and GuhaJ. (1995). Performance of some exotic mango germplasms under Bangladesh conditions. Bangladesh Hort.,23(1\&2): 17-22

Dhillon, W. S., Sharma, R. C. and Kahlon, G. S. (2004) Evaluation of some mango varieties under Punjab conditions. Haryana J. of Hort. Sci.,33 (3-4), 157-159

Doreyappa, I. N. G., Ramanjaneya, K. H., Iyer, C. P. A, Subramanyam, M. D. and Dinesh,M. R. (1994). Physicochemical and Processing quality of four new Mango hybrids in comparison to two commercial cultivars.J. of Food Sci. and Technol.,31: $385-388$

Hoda, M. N., Singh, S. and Singh J. (2003). Evaluation of ecological groups of mango (Mangifera indica L.) cultivars for flowering under Bihar conditions. The Indian $J$. of Agri. Sci., 73 (2):101-105

Hoogendijk, M. and Williams, D. (2001). Characterizing the genetic diversity of home garden Crops: Some examples from Americas. 2nd International Home gardens workshop, 17-19 July 2001, Witzenhausen, Federal Republic of Germany. Pp. 34-40

IPGRI.(2006). Descriptors for mango (Mangifera indica L).International Plant Genetic Resources Institute, Rome

Jilani, M. S., Bibi, F., Waseem, K. and Khan, M. A. (2010). Evaluation of physic-chemical characteristics of mango (MagniferaindicaL.) cultivars grown in D.I. Khan. $J$. of Agri. Res., 48(2): 201-207

Khan, M. D. (2004). Advances in mango hybridization. In: Mangoes in Pakistan. (Ed.): S. Ahmed

Kher, R and Sharma,R. M. (2002). Performance of some mango cultivars under sub-tropical rainfed regions of Jammu. Haryana J. of Hort. Sci.,31(1/2): 8-9

Kumar, R. Rajan, S. and Negi, S. S. (1999). Hierarchical approach for analyzing diversity in canopy characteris- tics of mango, Proceedings of the sixth international mango symposium: Working abstracts and program, 106: pp276

Kumar, N. (1998). Physico-chemical characteristics of mango varieties under Bhagalpur bihar conditions. Progress. Hort., 30(1-2): 28-35

Kundu, S. and Ghosh, S. N. (1992). Studies on physico chemical characteristics of mango cultivars grown in the laterite tract of West Bengal. Haryana J. of Hort. Sci. 21: $129-34$

Litz, R. E. (2009). The Mango Botany Production and Uses, $2^{\text {nd }}$ edition, CABI International.58-69

Majumder, D. A. N., Hassan L., Rahim M. A. and Kabir M. A. (2011).Studies on physio-morphology, floral biology and fruit characteristics of mango. J. Bangladesh Agril. Univ., 9(2): 187-199

Mannan, M. A., Khan, S. A. K. U., Islam, M. R., Islam, M. S and Siddiqa, A. (2003). A Study on the Physicochemical characteristics of some Mango varieties in Khulna Region. Pakistan J. of Biol. Sci., 6 (24): 20342039

Mitra, S. and Mitra, S. K. (2001). Studies on physicochemical characteristics of 19 mango varieties grown in West Bengal. Indian Agriculturist., 45(3/4); 215-219

Mitra, S., Kundu, S and Mitra. S. K. (2001). Evaluation of local strains of mango (Mangifera indica) grown in West Bengal. Indian J. of Agri. Sci.,71(7): 446-468

Palaniswamy, K. P., Muthukrishan, C. R. and Shanmugavclu, K. G. (1975). Physicochemical Characteristics of Some Varieties of Mango.Ind. Food Packer.,28: 12-19

Perrier, X. and Jacquemound-Collet., J.P. (2006). DARWin Dissimilarity Analysis and Representation for Windows. Agricultural Research for Development

Ranganna, S. (1986). Handbook of Analysis and Quality Control for Fruit and Vegetable Products. Tata $\mathrm{Me}$ Graw- HillPublishing Company, New Delhi, 1112p

Samad, M. A., Farruque, A. M. M. and Malek, A. (1975). A Study on the biochemical characteristics of the fruit of some mango variety of Bangladesh. Bangladesh $J$. of Scientific Res., 12: 28-32

Sharma, J. N and Josan, J. S. (1995). Performance of mango cultivars under arid irrigated regions of Punjab. Indian J. of Hort., 52(3): 179-181

Singh, R. D and Bana, D. S. (1976). Studies on mango varieties, morphological and physico-chemical studies of some varieties. Indian J. of Agri. Res., 10(3): 159

Singh, S. (2002). Evaluation of mango cultivars for their flowering, fruiting and fruit quality attributes. Prog. Hort.,34(2): 240-243

Teaotia, S. S, Singh, R. D. and Awasthi, R. K. (1972). Studies on mango (Mangiferaindica L.) varieties. II. Morphological and physico-chemical studies of some important table varieties. Punjab Hort. J., 12(8): $152-157$ 